\title{
Survival of Viral Biowarfare Agents in Disinfected Waters
}

\author{
Mary Margaret Wade, ${ }^{1}$ Amanda E. Chambers, ${ }^{1}$ Joseph M. Insalaco, ${ }^{2}$ and Alan W. Zulich ${ }^{1}$ \\ ${ }^{1}$ Edgewood Chemical Biological Center, U.S. Army, RDECOM, Edgewood Area, Aberdeen Proving Ground, \\ Aberdeen, MD 21010, USA \\ ${ }^{2}$ Science Applications International Corporation, P.O. Box 68, Gunpowder, Branch, Aberdeen, MD 21010, USA \\ Correspondence should be addressed to Mary Margaret Wade, mary.m.wade@us.army.mil
}

Received 2 July 2010; Accepted 10 November 2010

Academic Editor: Joseph Falkinham

Copyright ( 2010 Mary Margaret Wade et al. This is an open access article distributed under the Creative Commons Attribution License, which permits unrestricted use, distribution, and reproduction in any medium, provided the original work is properly cited.

\begin{abstract}
Protecting civilian and military water supplies has received more attention since the United States began its war on terror in 2001. Both chlorine and bromine are used by branches of the U.S. military for disinfecting water supplies; however, limited data exists as to the effectiveness of these additives when used against viral biowarfare agents. The present study sought to evaluate the survival of selected viral biothreat agents in disinfected water. Disinfected water samples were spiked with vaccinia virus strain WR and Venezuelan equine encephalitis (VEE) virus strain TC- 83 each separately to a final concentration of approximately $1 \times 10^{6} \mathrm{PFU} / \mathrm{mL}$, and survival was assessed by plaque assay. Both viruses were inactivated by $1 \mathrm{mg} / \mathrm{L}$ free available chlorine (FAC) and $2 \mathrm{mg} / \mathrm{L}$ total bromine within one hour. In conclusion, these results demonstrate that both chlorine and bromine are effective disinfectants against vaccinia virus and VEE strain TC-83 at the concentrations tested.
\end{abstract}

\section{Introduction}

Since the tragic events of 2001, concern among many government agencies has risen with regard to protecting the nation's critical water infrastructure. And although chlorination is commonly used in the U.S. for disinfecting drinking water $[1,2]$, little data currently exits with regard to the persistence of biowarfare agents in chlorinated water, particularly viral biowarfare agents. Studies have been performed examining chlorine inactivation of bacterial biothreat agents [3-5], but few studies have examined free chlorine inactivation of viral biothreat agents, such as those that cause viral hemorrhagic fevers, viral encephalitis, or smallpox. One study examining the survival of the vaccine strain of Venezuelan equine encephalitis (VEE) virus in liquids reported that VEE strain TC-83 was reduced by more than $5 \log _{10}$ within the 21 days in tap water with chlorine (between 4 and $5 \mathrm{mg} / \mathrm{L}$ ), yet survived in distilled-deionized water at $4^{\circ} \mathrm{C}$ for the duration of the 21-day study [6].

Many branches of the armed services use chlorine to disinfect water; however, the U.S. Navy often utilizes bromine onboard ships for the same purpose and even less is known about the effectiveness of bromine against biothreat agents.
Therefore, in the present study the U.S. Army Edgewood Chemical Biological Center (ECBC) sought to investigate the survival of selected viral biowarfare agents in waters representative of those used by branches of the military to include both chlorinated and brominated water using military relevant concentrations of each disinfectant. Smallpox and VEE are both considered potential bioterrorism agents and as such pose a high risk to national security. Both can be easily to moderately disseminated or transmitted and result in high to moderate mortality rates. Therefore, it was desired to investigate survival of these particular potential agents of bioterrorism in disinfected waters. Specifically, vaccinia virus (Smallpox surrogate) and VEE virus strain TC-83, which are avirulent representatives of the Category A and Category B agents, respectively, were employed in the present study.

\section{Materials and Methods}

2.1. Formulated Tap Water Preparation. Concentrated stock solutions were prepared using ASTM Type I deionized water and were stored at $4^{\circ} \mathrm{C}$ with a shelf life of 6 months (see Table 1 for list of stock solutions). Once stock solutions were prepared, approximately $500 \mathrm{~mL}$ of ASTM Type I deionized 
TABLe 1: Preparation of formulated tap water.

\begin{tabular}{lccc}
\hline Chemical & $\begin{array}{c}\text { Concentration } \\
\text { of Stock } \\
(\mathrm{mg} / \text { liter })\end{array}$ & $\begin{array}{c}\text { Amount of } \\
\text { Stock added } \\
(\mathrm{mL})\end{array}$ & $\begin{array}{c}\text { Final } \\
\text { concentration } \\
(\mathrm{mg} / \text { liter })\end{array}$ \\
\hline $\mathrm{NaHCO}_{3}$ & 10,000 & 10.0 & 100 \\
$\mathrm{MgSO}_{4} \cdot 7 \mathrm{H}_{2} \mathrm{O}$ & 1,000 & 13.4 & 13.4 \\
$\mathrm{~K}_{2} \mathrm{HPO}_{4}$ & 1,000 & 0.7 & 0.700 \\
$\mathrm{KH}_{2} \mathrm{PO}_{4}$ & 1,000 & 0.3 & 0.300 \\
$\left(\mathrm{NH}_{4}\right)_{2} \mathrm{SO}_{4}$ & 100 & 0.1 & 0.0100 \\
$\mathrm{NaCl}_{\mathrm{FeSO}} \cdot 7 \mathrm{H}_{2} \mathrm{O}$ & 100 & 0.1 & 0.0100 \\
$\mathrm{NaNO}_{3}$ & 1,000 & 0.1 & 0.001 \\
$\mathrm{CaSO}_{4}$ & 1,000 & 1.0 & 1.00 \\
$\mathrm{Humic} \mathrm{acid}^{\mathrm{a}}$ & 1,000 & 27.0 & 27.0 \\
Fulvic acid $^{\mathrm{b}}$ & 1,000 & 1.0 & 1.00 \\
\hline
\end{tabular}

(a) IHSS Suwannee River Humic Acid Standard, Cat. No. 1S101H.

(b) IHSS Suwannee River Fulvic Acid Standard, Cat. No. 1S101F.

water was added to a 1-liter volumetric flask. Then each stock solution was added in the appropriate amount to achieve the desired final concentration (refer to Table 1) and the total volume was brought to 1 liter with deionized water. After 1520 minutes, the $\mathrm{pH}$ was assessed and adjusted if needed (with minimal volume change) to 7.6-7.8. Once prepared, formulated tap water was stored at $4^{\circ} \mathrm{C}$ with a shelf life of one week.

2.2. Chlorine Stock Solution Preparation. 1.00 gram of calcium hypochlorite (Logistics NSNno. 6840-00-255-0471, containing $65 \%$ available chlorine) was weighed and placed into a $22 \mathrm{~mL}$ glass vial. $20.0 \mathrm{~mL}$ of ASTM Type I deionized water was added, and the vial was capped and shaken vigorously for 1-2 minutes. The solids were allowed to settle for 5-10 minutes before using. The chlorine stock solution was used within eight hours.

2.3. Chlorine Addition. $15 \mu \mathrm{L}$ of the chlorine stock solution (supernatant, not solids) was added to $100 \mathrm{~mL}$ of the formulated tap water. The free available chlorine (FAC) was measured using a Hach DR 2500 spectrophotometer per manufacturer's instructions (Hach Company, Loveland, $\mathrm{CO})$. Chlorinated water was not considered stable and therefore was made fresh daily just prior to use. All glass bottles or vials were preconditioned with chlorinated water prior to the first use by soaking overnight. In addition, old chlorinated water was left in the bottle until a new batch was made in order to reduce the chlorine demand of the bottle surfaces.

2.4. Bromine Addition. A brominating cartridge (EVERPURE, P/N 255340-416, $1.25 \mathrm{~kg}$ of brominated resin, 30\% bromine) was opened and approximately $25 \mathrm{~mL}$ of resin was transferred to a $500 \mathrm{~mL}, 0.20 \mu \mathrm{m}$ filter unit (Corning Life Science, Lowell, MA). Formulated tap water was poured into the same filter unit, filtered and collected. The bromine resin was retained by the filter. Total residual bromine in the collected formulated tap water was measured using a Hach DR 2500 spectrophotometer per manufacturer's instructions (Hach Company Loveland, CO). The total residual bromine level was adjusted if needed to achieve the desired final concentration of $2 \mathrm{mg} / \mathrm{L}$ by either diluting the sample with formulated tap water or passing (refiltering) the sample back over the bromine resin. Brominated water was not considered stable and therefore was made fresh daily just prior to use.

2.5. Cell Lines and Virus Source. Vero cells (CCL-81), BSC-40 cells (CRL-2761), and BHK-21 cells (CCL-10) were obtained from ATCC (Manassas, VA). Vaccinia virus strain WR and Venezuelan Equine Encephalitis virus strain TC-83 (VEE TC83) were also obtained from ATCC. Vaccinia virus served as a biosafety level 2 surrogate for Variola major (smallpox) and the vaccine strain of VEE (TC-83) also served as a surrogate for virulent VEE. All cells were grown at $37^{\circ} \mathrm{C}$ with $5 \% \mathrm{CO}_{2}$ in Dulbecco's Modified Eagle's Medium (DMEM) containing $10 \%$ heat-inactivated fetal bovine serum (FBS). Cells were passed on a twice weekly basis, and media were replaced daily.

2.6. Vaccinia Propagation. Vaccinia virus was propagated in $\mathrm{BHK}-21$ monolayer cultures at $37^{\circ} \mathrm{C}$. Cells were infected with virus for 1 hour in DMEM at $37^{\circ} \mathrm{C}$. Following the absorption period, media were removed and replaced with fresh DMEM containing 10\% FBS. Infected cells were harvested 48 hours postinfection and centrifuged at $650 \times \mathrm{g}$ at $4^{\circ} \mathrm{C}$ for 10 minutes. Pellets were resuspended in cell culture medium, freeze-thawed for three cycles, sonicated for four minutes on ice, and centrifuged at $650 \times \mathrm{g}$ at $4^{\circ} \mathrm{C}$ for 10 minutes. The supernatant served as the source for virus. The resulting virus served as the source of vaccinia for all experiments described below.

2.7. VEE Propagation. VEE strain TC-83 virus was propagated in Vero monolayer cultures at $37^{\circ} \mathrm{C}$. Cells were infected with virus for one hour in DMEM at $37^{\circ} \mathrm{C}$. Following the absorption period, media were removed and replaced with DMEM containing $10 \% \mathrm{FBS}$ at $37^{\circ} \mathrm{C}$. Infected cells were harvested and centrifuged at $650 \times \mathrm{g}$ at $4^{\circ} \mathrm{C}$ for 10 minutes. The supernatant was saved and stored at $-80^{\circ} \mathrm{C}$ and served as the source of VEE strain TC-83 for all experiments described below.

2.8. Plaque Assays. BSC-40 cells (host of vaccinia virus) or Vero cells (host of VEE TC-83) were plated at a density of $3.0 \times 10^{5}$ cells per well in twelve-well plates. Cells were allowed to reach confluence overnight at $37^{\circ} \mathrm{C}$ in DMEM containing $10 \%$ FBS. Prior to dilution, the vaccinia stock was sonicated on ice for 30 seconds. The virus was serially diluted from $1: 10^{2}$ to $1: 10^{9}$ in DMEM. The medium was removed from the cells, and the diluted virus was added. Virus absorption was for one hour at $37^{\circ} \mathrm{C}$ with occasional shaking. Following absorption, medium was removed and replaced with minimal essential medium (MEM) containing 5\% FBS and 1\% SeaPlaque Agarose. Forty-eight hours after 
infection, the cells were fixed in $7 \%$ formaldehyde for one hour. The agarose layer was removed, and cells were fixed for an additional hour in 7\% formaldehyde. After removing the formaldehyde, plaques were visualized by staining with $0.01 \%$ crystal violet for 30 minutes. The plaques were counted, and the results were reported in plaque forming units per milliliter $(\mathrm{pfu} / \mathrm{mL})$.

2.9. Inoculation, Incubation, and Sampling. Survival of vaccinia virus strain WR and VEE TC-83 in chlorinated and brominated water (preparation of each described above) was determined by inoculating each water matrix with virus to a final concentration of approximately $1 \times 10^{6} \mathrm{PFU} / \mathrm{mL}$. At various time intervals, $1 \mathrm{~mL}$ of the spiked water sample was removed and sodium thiosulfate was added to a final concentration of $0.005 \%$ to quench any remaining disinfectant (Sigma Chemical Company, St. Louis, MO). The samples were serial diluted, and plaque assay was performed as described above. All water matrices tested were filter sterilized prior to inoculation. All samples were incubated at room temperature $\left(21^{\circ} \mathrm{C}\right)$ after inoculation, and each virus was tested separately in each water. Military relevant time points were selected per guidance from the funding agency.

\section{Results}

Survival of vaccinia virus strain WR and VEE strain TC83 in both chlorinated and brominated water over time is presented in Figures 1 and 2, respectively. All data is presented as the number of $\mathrm{PFU} / \mathrm{mL}$ recovered over time by plaque assay. As shown in Figures 1 and 2, both viruses persisted in positive control samples, which consisted of formulated tap water without disinfectant, with no decrease in viability for the time points tested. However, in the presence of $1 \mathrm{mg} / \mathrm{L}$ FAC and $2 \mathrm{mg} / \mathrm{L}$ total bromine, neither virus was infectious at the earliest time point tested of one hour or at any subsequent time points tested.

\section{Discussion}

Although disinfection of water supplies is common practice in the U.S., limited data is currently available with regard to the length of time viral biothreat agents can survive in those waters. Both chlorination and bromination of water are practiced by branches of the military and therefore both were included at military relevant concentrations in the present study in order to ascertain their effectiveness as disinfectants against selected viruses. Survival of vaccinia virus strain WR and VEE strain TC-83 in formulated tap water with bromine or chlorine was monitored over time at room temperature using plaque assay to assess infectivity of the virus. Both disinfectants proved to be effective sanitizers against the viral biowarfare agents tested in a minimal amount of time making this study one of the first to report the survival of viral biothreat agents in chlorinated, and, moreover, brominated water.

The U.S. Army and other government entities, in an effort to protect national and military water supplies, are

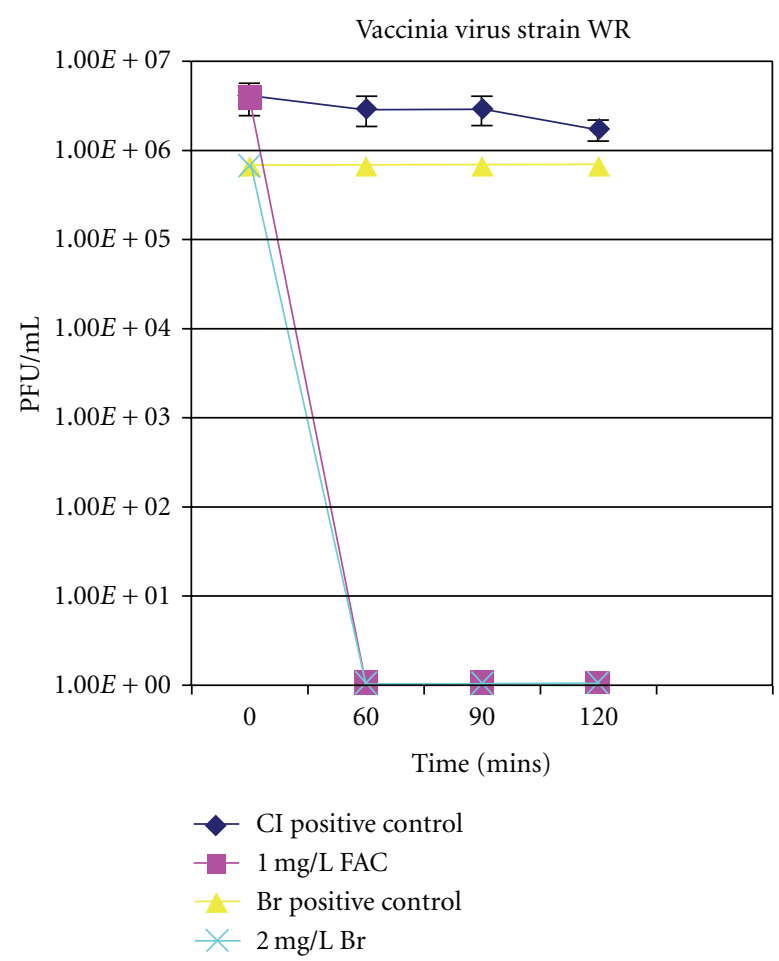

FIgURE 1: Survival of vaccinia virus strain WR in formulated tap water with $1 \mathrm{mg} / \mathrm{L}$ FAC and $2 \mathrm{mg} / \mathrm{L}$ total bromine. Positive control samples consisted of formulated tap water without disinfectant. All samples were incubated at $21^{\circ} \mathrm{C}$, and, at intervals, viral titers were determined as described in Materials and Methods.

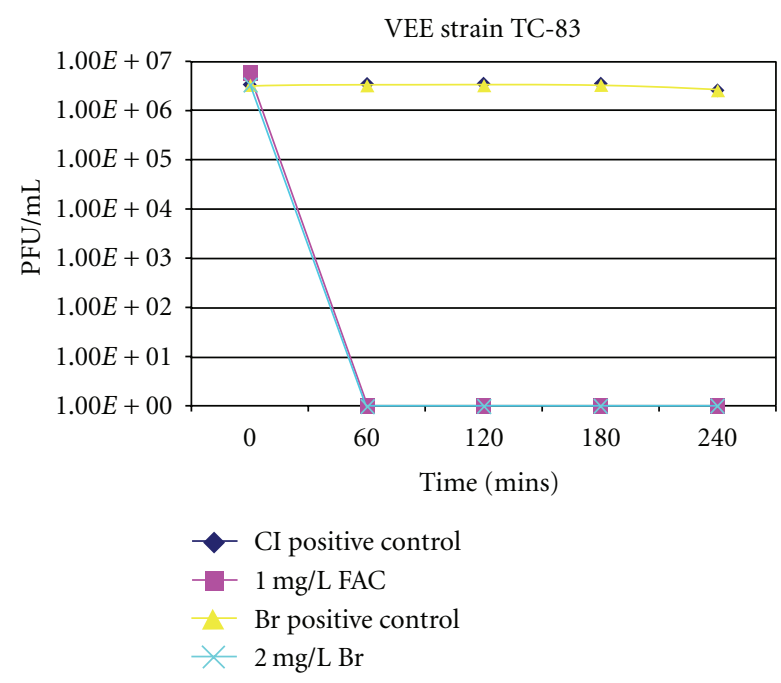

FIGURE 2: Survival of VEE strain TC-83 in formulated tap water with $1 \mathrm{mg} / \mathrm{L}$ FAC and $2 \mathrm{mg} / \mathrm{L}$ total bromine. Positive control samples consisted of formulated tap water without disinfectant. All samples were incubated at $21^{\circ} \mathrm{C}$, and, at intervals, viral titers were determined as described in Materials and Methods.

placing great emphasis on developing rapid detection and identification technologies for biological agents in water. However, based on data provided in this study, monitoring chlorine or bromine levels in water supplies to ensure 
that adequate levels of disinfectant are present could prove sufficient for maintaining safe water supplies. Additional testing with a greater number of agents will be required before this decision can be made, and these tests are already underway to evaluate whether additional agents are easily killed by chlorination and bromination.

\section{Acknowledgment}

This work was supported by the Defense Threat Reduction Agency.

\section{References}

[1] G. F. Council, J. C. Routt, B. Macler et al., "Committee report: disinfection at small systems AWWA water quality division disinfection systems committee," Journal of the American Water Works Association, vol. 92, no. 5, pp. 24-31, 2000.

[2] G. F. Connell, J. C. Routt, B. Macler et al., "Committee report: disinfection at large and medium-size systems AWWA water quality division disinfection systems committee," Journal of the American Water Works Association, vol. 92, no. 5, pp. 32-43, 2000.

[3] L. J. Rose, E. W. Rice, B. Jensen et al., "Chlorine inactivation of bacterial bioterrorism agents," Applied and Environmental Microbiology, vol. 71, no. 1, pp. 566-568, 2005.

[4] K. Howard and T. J. J. Inglis, "Disinfection of Burkholderia pseudomallei in potable water," Water Research, vol. 39, no. 6, pp. 1085-1092, 2005.

[5] H. A. O'Connell, L. J. Rose, A. Shams, M. Bradley, M. J. Arduino, and E. W. Rice, "Variability of Burkholderia pseudomallei strain sensitivities to chlorine disinfection," Applied and Environmental Microbiology, vol. 75, no. 16, pp. 5405-5409, 2009.

[6] J. E. Fitzgibbon and J. L. Sagripanti, "Analysis of the survival of Venezuelan equine encephalomyelitis virus and possible viral simulants in liquid suspensions," Journal of Applied Microbiology, vol. 105, no. 5, pp. 1477-1483, 2008. 

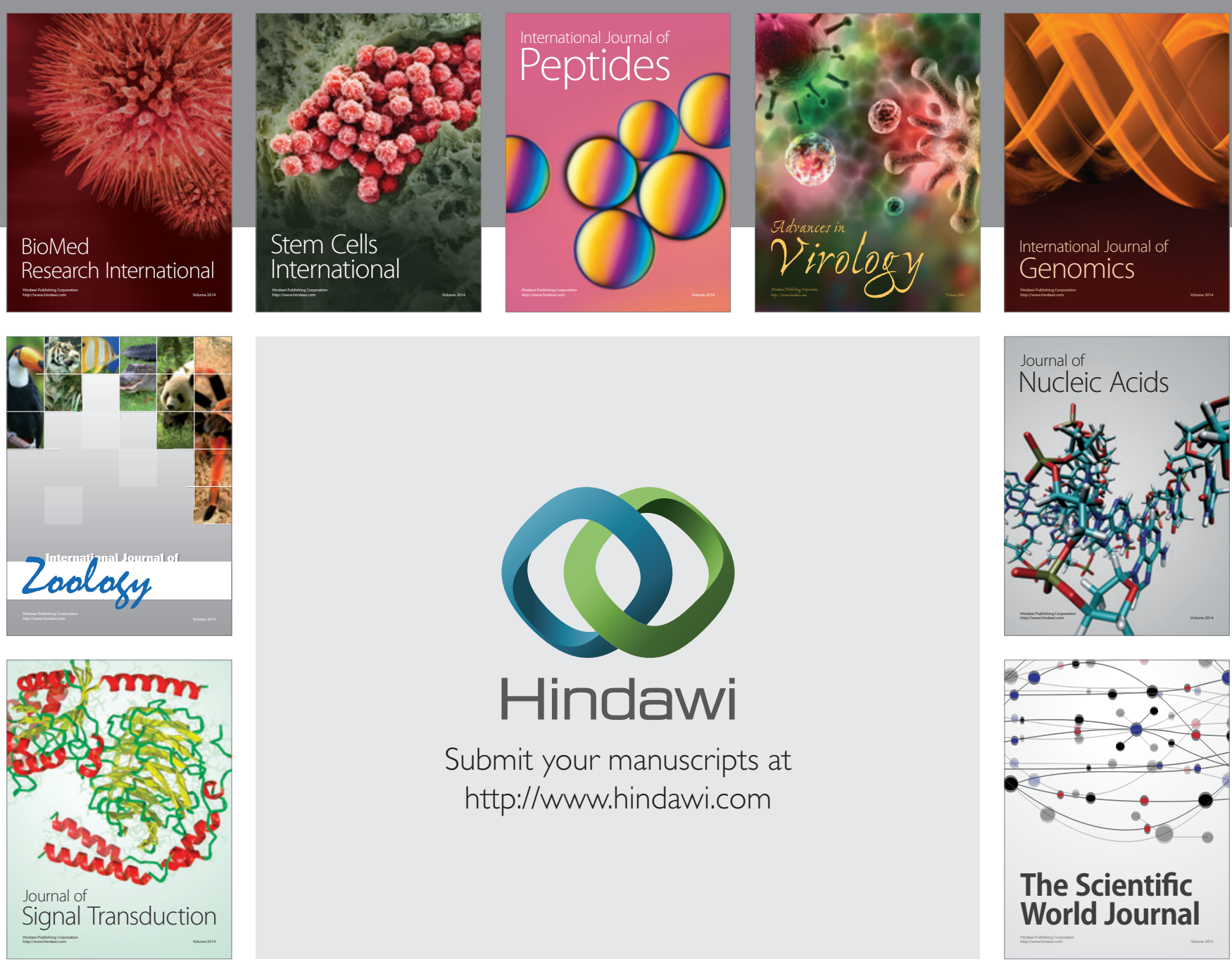

Submit your manuscripts at

http://www.hindawi.com
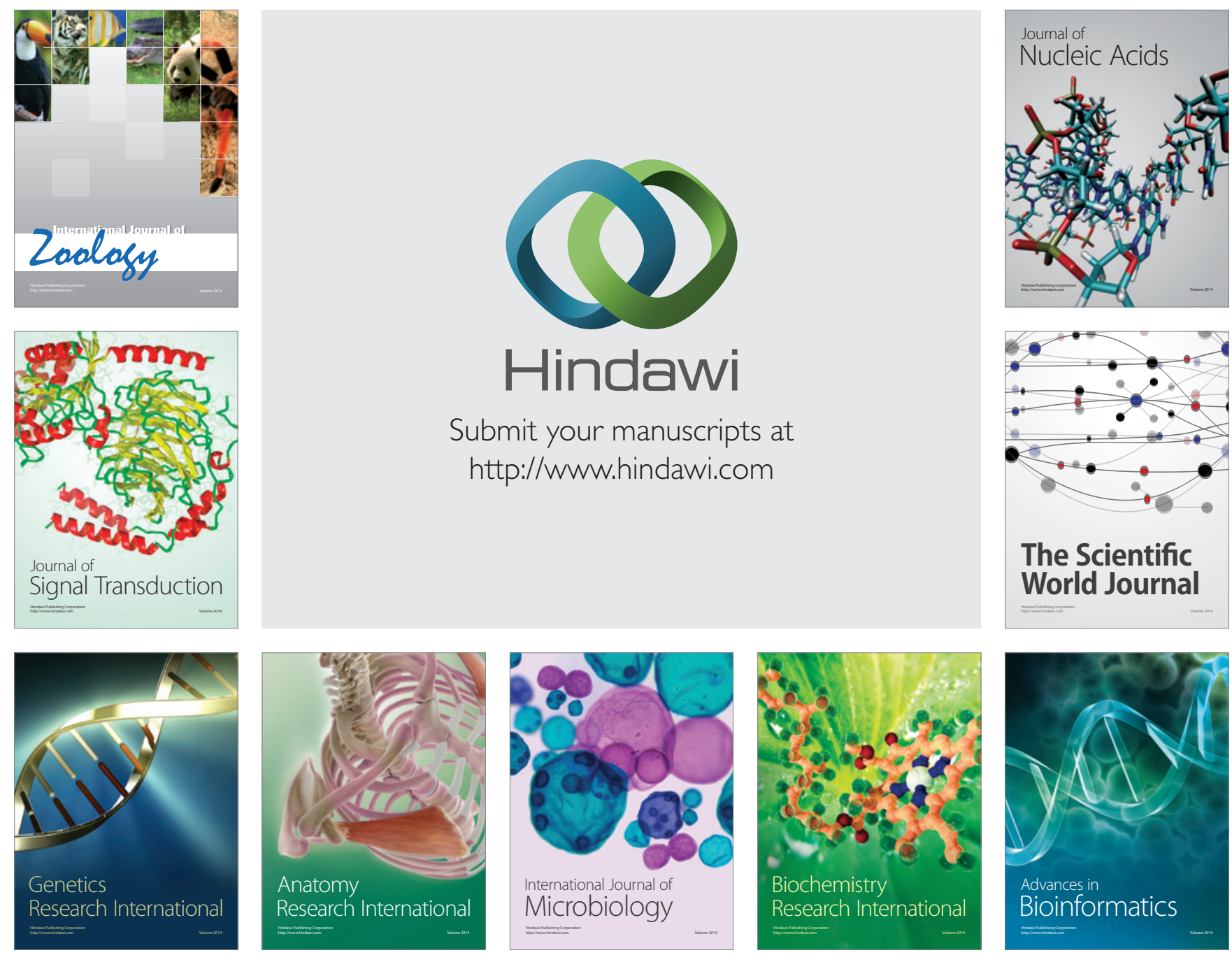

The Scientific World Journal
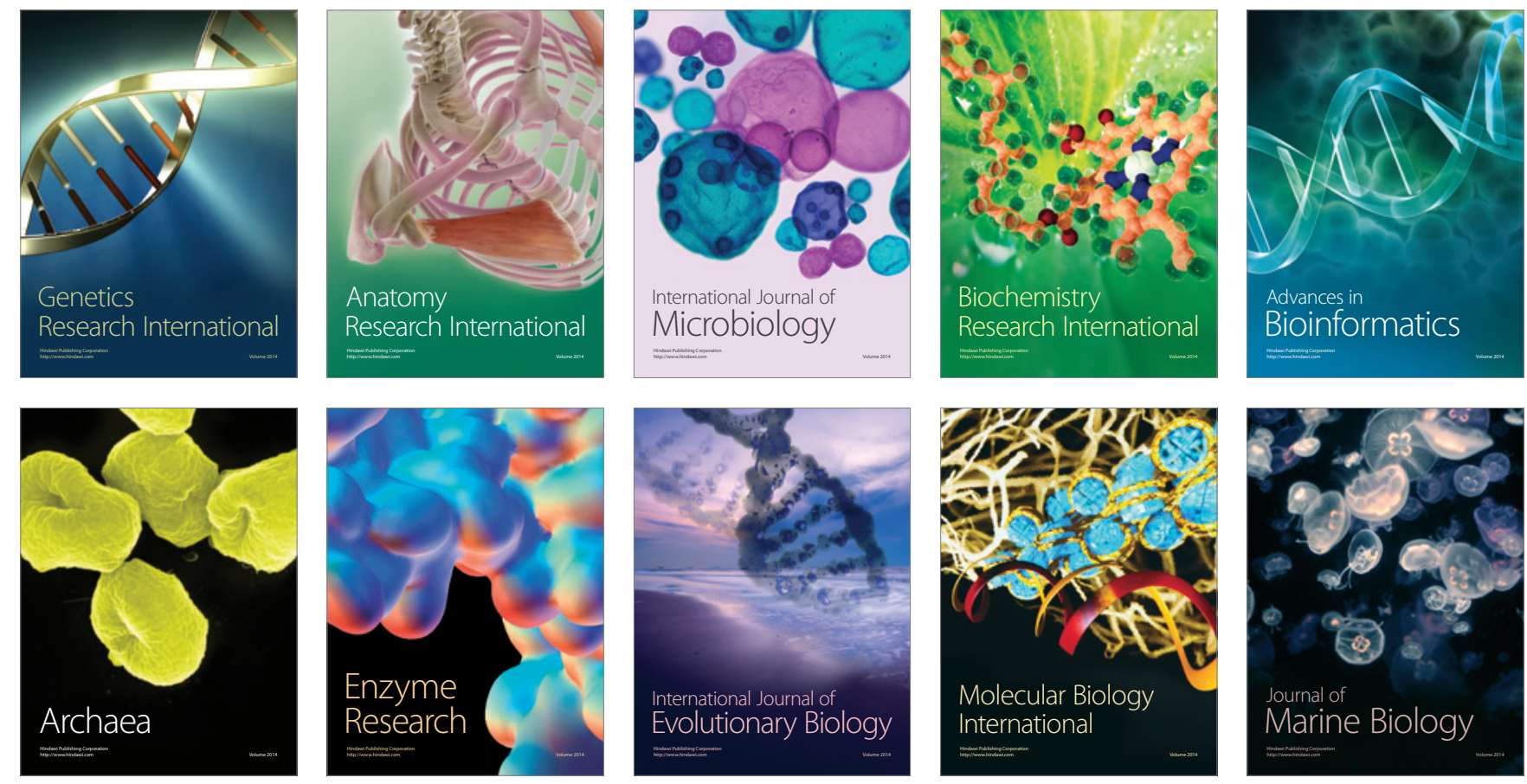